University of Nebraska - Lincoln

DigitalCommons@University of Nebraska - Lincoln

USDA Wildlife Services - Staff Publications

U.S. Department of Agriculture: Animal and Plant Health Inspection Service

2013

\title{
Humoral immune response to oral rabies vaccination in raccoon kits: Problems and implications
}

Tricia L. Fry

USDA/APHIS/Wildlife Services' National Wildlife Research Center, tricia.I.fry@aphis.usda.gov

Kaci K. VanDalen

USDA/APHIS/WS National Wildlife Research Center, kaci.vandalen@aphis.usda.gov

Susan A. Shriner

USDA/APHIS/WS National Wildlife Research Center, susan.a.shriner@aphis.usda.gov

Susan M. Moore

Kansas State University Rabies Laboratory, smoore@vet.k-state.edu

Cathleen A. Hanlon

Kansas State University Rabies Laboratory, chanlon@vet.k-state.edu

See next page for additional authors

Follow this and additional works at: https://digitalcommons.unl.edu/icwdm_usdanwrc

Fry, Tricia L.; VanDalen, Kaci K.; Shriner, Susan A.; Moore, Susan M.; Hanlon, Cathleen A.; and Vercauteren, Kurt C., "Humoral immune response to oral rabies vaccination in raccoon kits: Problems and implications" (2013). USDA Wildlife Services - Staff Publications. 1228.

https://digitalcommons.unl.edu/icwdm_usdanwrc/1228

This Article is brought to you for free and open access by the U.S. Department of Agriculture: Animal and Plant Health Inspection Service at DigitalCommons@University of Nebraska - Lincoln. It has been accepted for inclusion in USDA Wildlife Services - Staff Publications by an authorized administrator of DigitalCommons@University of Nebraska - Lincoln. 


\section{Authors}

Tricia L. Fry, Kaci K. VanDalen, Susan A. Shriner, Susan M. Moore, Cathleen A. Hanlon, and Kurt C. Vercauteren 


\title{
Humoral immune response to oral rabies vaccination in raccoon kits: Problems and implications
}

\author{
Tricia L. Fry ${ }^{\mathrm{a}}$, Kaci K. VanDalen ${ }^{\mathrm{a}, *}$, Susan A. Shriner ${ }^{\mathrm{a}}$, Susan M. Moore ${ }^{\mathrm{b}}$, Cathleen A. Hanlon ${ }^{\mathrm{b}}$, \\ Kurt C. VerCauteren ${ }^{a}$

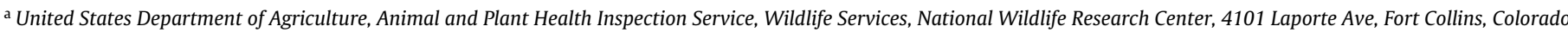 \\ 80521, USA \\ ${ }^{\mathrm{b}}$ Kansas State University Rabies Laboratory, 2005 Research Park Circle, Manhattan, Kansas 66502, USA
}

\section{A R T I C L E I N F O}

\section{Article history:}

Received 15 January 2013

Received in revised form 4 April 2013

Accepted 7 April 2013

Available online 18 April 2013

\section{Keywords:}

Raccoon kits

Oral rabies vaccination

Procyon lotor

Rabies

Raboral V-RG

Maternal antibodies

\begin{abstract}
A B S T R A C T
Little is known about the immunogenicity of RABORAL V-RG ${ }^{\circledR}$ (V-RG), an oral rabies vaccine, in raccoon kits (Procyon lotor). The objectives of this study were to characterize the immunogenicity of $\mathrm{V}$-RG in young kits and investigate the potential impact of maternal antibodies on response to vaccination of nursing raccoon kits. Raccoon kits $(n=30)$ were vaccinated at either 3 weeks of age, 7 weeks of age, or assigned as contact controls. Nineteen kits (73\%) that were whelped by unvaccinated mothers responded to VRG exposure (orally or indirect contact) by production of detectable rabies virus neutralizing antibodies (RVNA) while 7 (27\%) kits did not respond to V-RG exposure. Four kits were whelped by a mother with high levels of RVNA and all four kits acquired maternal rabies antibodies. At approximately 9 months of age, all kits were inoculated with a killed rabies vaccine, IMRAB3 ${ }^{\circledR}$. The kits which initially responded to V-RG oral vaccination or contact with vaccinated littermates demonstrated a rapid anamnestic response. In contrast, the V-RG non-responders and those with acquired maternal antibodies exhibited a primary immune response to IMRAB3 ${ }^{\circledR}$, where RVNA levels were substantially lower on days 5 and 7 than the levels in the animals with an anamnestic response. These findings suggest that the naïve contact kits and the nonresponsive kits most likely remained susceptible to rabies virus infection whereas the ones demonstrating response to V-RG would not have been susceptible to a rabies virus infection.
\end{abstract}

Published by Elsevier Ltd.

\section{Introduction}

Rabies is one of the oldest diseases described with records of clinical manifestations in humans dating back to 2300 B.C. It is estimated that more than 55,000 people die of rabies each year and another 20 million receive rabies post exposure prophylaxis [1]. Throughout most of the world, domestic dogs remain the most common reservoir for local transmission of canine-associated rabies virus variants; however, in the United States the dominant virus variants are associated with wildlife species [2]. Rabies viruses consist of a number of unique variants that are adapted to specific hosts [3]. The animals most frequently reported with rabies in the United States are raccoons (Procyon lotor), insectivorous bats (Chiroptera spp.), striped skunks (Mephitis mephitis), foxes of several

\footnotetext{
* Corresponding author. Tel.: +1 970266 6312; fax: +1 9702666138.

E-mail addresses: tricia.l.fry@aphis.usda.gov (T.L. Fry), kaci.vandalen@aphis.usda.gov (K.K. VanDalen), susan.a.shriner@aphis.usda.gov (S.A. Shriner), smoore@vet.k-state.edu (S.M. Moore), chanlon@vet.k-state.edu (C.A. Hanlon), kurt.c.vercauteren@aphis.usda.gov (K.C. VerCauteren).
}

species (Vulpes lagopus, Vulpes vulpes, and Urocyon cinereoargenteus), and coyotes (Canis latrans) [4,5]. As an augment to traditional reactive public health measures, oral rabies vaccination (ORV) campaigns have been implemented on an experimental basis in strategic locations in an attempt to control the spread of expanding terrestrial epizootics. The effectiveness of ORV programs, most notably those directed toward control of rabies virus variants in Europe and North America has been previously reviewed [6,7].

The National Rabies Management Program, administered by USDA-APHIS Wildlife Services, is tasked with controlling the spread of terrestrial wildlife-associated rabies in the United States. At present, the majority of ORV efforts involve the distribution of a live recombinant vaccine, RABORAL V-RG ${ }^{\circledR}$ (V-RG, Merial Inc., Athens, GA, USA). V-RG is currently the only effective oral vaccine licensed for use in free-ranging raccoons and coyotes in the United States [8]. In the eastern United Sates, the main focus of ORV campaigns is the raccoon rabies variant, which has spread and evolved since the 1970 s into a widespread epizootic $[9,10]$. As a consequence of wildlife translocation from the southeast United States raccoon rabies was introduced into the Mid-Atlantic States and now extends north into Canada and across the Appalachian mountains 
as far west as Ohio [11]. Generally, raccoon ORV campaigns with V-RG commence in late summer or early fall when raccoon population density peaks [12]. While considerable research has been done on vaccination of adult raccoons, few published studies are available on the vaccine's immunogenicity and efficacy in young raccoons. Rupprecht et al. reported that three suckling raccoon kits (3-4 weeks olds) seroconverted within 28 days after their mother was orally vaccinated with V-RG, although the mode of transmission, either grooming or lactation was not ascertained. Subsequently, all three kits survived a rabies virus challenge [13]. Maternal antibodies can be passively transferred to young through the placenta, yolk sac, colostrum, and/or milk [14] depending upon the species and the type of placentation and other aspects of the species physiology. Maternal neutralizing antibodies to rabies virus $(\geq 0.5 \mathrm{IU} / \mathrm{mL})$ can circulate for several weeks in fox cubs [15-17]. Blasco et al. [15] observed the disappearance of maternal antibodies in fox cubs corresponded to approximately 10-20 days after weaning. The duration of maternally derived antibodies to rabies virus in raccoon kits has not been published but may be similar to the half-life of raccoon maternal antibodies to canine distemper virus, which is approximately 10.55 days post-weaning [18]. While the role of maternal antibodies is to protect a young animal with an immature immune system from harmful pathogens, it has been shown that the presence of circulating maternal antibodies in young animals may interfere with the response to some vaccinations [18-20]. Research examining the maternal antibody-rabies vaccination interference in wildlife has been limited to reports in red foxes with Blasco et al. [15] reporting that maternal immune status did not interfere with the oral rabies vaccination of cubs once maternal antibodies disappeared $(<0.5 \mathrm{IU} / \mathrm{mL})$ between 45 and 75 days old.

The specific objectives of this study were to: (1) monitor rabies virus neutralization antibody (RVNA) levels in very young raccoon kits following exposure to V-RG, (2) determine a raccoon kit's ability to produce an anamnestic response following a second exposure to the rabies antigen (in this case, the killed rabies vaccine IMRAB3 ${ }^{\circledR}$ (Merial Inc., Athens, GA, USA)), (3) determine how long maternally derived antibodies circulate in young raccoons and, (4) demonstrate whether or not maternal antibodies to rabies virus interfere with V-RG vaccination.

\section{Materials and methods}

\subsection{Study animals}

As the result of another research project seven wild caught female raccoons became pregnant and whelped at least one kit. The female raccoons were trapped from within Larimer County, Colorado, USA and housed in the Outdoor Animal Research Facility at the USDA APHIS WS National Wildlife Research Center (NWRC), Fort Collins, CO, USA. Three of the females with litters had been previously vaccinated with IMRAB $3^{\circledR}$, a killed rabies vaccine. Of the three vaccinated females, only one had detectable RVNA $(14.4 \mathrm{IU} / \mathrm{mL})$ one month prior to whelping. Four kits were born and weaned by this female. The four females which were not vaccinated and the two IMRAB $3^{\circledR}$ vaccinates that did not have detectable RNVA $(<0.1 \mathrm{IU} / \mathrm{mL})$ whelped a total of 26 raccoon kits.

Raccoon kits were housed with their mothers for $\geq 14$ weeks, but not $>17$ weeks. Raccoon kits remained with litter mates for three weeks after weaning, at which time they were moved to individual pens. Raccoons were held in accordance with IACUC guidelines, and fed a varying, age appropriate diet that included Omnivore Diet A (Mazouri, St. Louis, MO, USA), milk replacer, canned cat food, mackerel, eggs, and various fresh fruits. Water was provided ad libitum.

\subsection{Blood collection}

We collected blood from each adult female raccoon approximately one month prior to whelping and again at weaning. We used 5:1 ketamine $(10 \mathrm{mg} / \mathrm{kg})$ and xylazine $(2 \mathrm{mg} / \mathrm{kg})$ mixture [21] to anesthetize adult raccoons and collected blood [22]. Starting at 10-14 days old we collected blood weekly for 26 weeks from raccoon kits. Blood collection and restraint techniques varied based on the age of the raccoon kits. Raccoon kits were primarily physically restrained or anesthetized using isoflurane until they were housed individually. Once housed individually we anesthetized raccoons using a 5:1 ratio of ketamine: xylazine as described above. We collected blood samples via the jugular vein with volumes ranging from $0.4 \mathrm{~mL}$ to $3 \mathrm{~mL}$ ( $\leq 1.5 \%$ body mass) [22] in Vacutainer SST ${ }^{\circledR}$ serum separator tubes (Becton Dickinson, Franklin Lakes, NJ, USA). We stored sera at $-80^{\circ} \mathrm{C}$ until it was sent to the Kansas State University Rabies Laboratory (Manhattan, KS, USA) for testing.

\subsection{Primary vaccination}

We arbitrarily assigned raccoon kits into one of three treatment groups: (1) vaccinated with V-RG at 3 weeks of age, (2) vaccinated at 7 weeks of age, or (3) unvaccinated (contact controls). Six litters had at least one representative of each group, except for one litter which consisted of a single kit that was vaccinated at 3 weeks of age. Vaccination consisted of $1.5 \mathrm{~mL}\left(10^{8.2} \mathrm{PFU}\right) \mathrm{V}-\mathrm{RG}$ administered orally via needleless syringe (Lot \#576-151, Merial, Ltd., Athens, GA, USA). Immediately after vaccination, we returned kits to their mothers and litter mates.

\subsection{Secondary vaccination to assess anamnestic responses}

An anmnestic response to the rabies virus after oral vaccination has been previously shown to increase the likelihood of raccoon survival [23]. To evaluate young raccoons' responses to a second rabies antigen exposure (in this case, a killed rabies vaccine, IMRAB $3^{\circledR}$ ), we inoculated all raccoon kits with IMRAB $3^{\circledR}$ (Serial: 12550, Merial, Ltd. Athens, GA, USA), between 38 and 41 weeks of age. We collected blood as previously described on days $0,5,7$, and 31 post-IMRAB $3{ }^{\circledR}$ inoculation (time points were designated as B0, B5, B7, and B31). We used a Student's $t$-test to evaluate an anamnestic response by comparing the differences in median RVNA values between B0 and (1) day B5, (2) day B7, and (3) day B31.

\subsection{Laboratory testing}

We sent aliquots of serum to Kansas State University Rabies Laboratory for detection and quantification of RVNA. RVNA were characterized by the Rapid Fluorescent Focus Inhibition Test (RFFIT); the $50 \%$ end point titer of the test serum was converted to IU/mL values by comparison to the $50 \%$ end point titer of the U.S. Standard Rabies Immune Globulin, Lot R-3, 59 IU (1st WHO International Standard), which is measured in the same assay run, with an assigned value of $2.0 \mathrm{IU} / \mathrm{mL}$ [24,25]. Sero-status of raccoons was determined based on a detection threshold of $0.1 \mathrm{IU} / \mathrm{mL}$ to increase sensitivity [26].

\section{Results}

\subsection{Antibody responses of raccoon kits after initial vaccination}

Six litters ( $n=26$ kits) were whelped by seronegative mothers and subsequently had no detectable RVNA 2-3 weeks after birth. Ten of these raccoon kits were vaccinated at 3 weeks of age and nine (90\%) developed RVNA at an average of 5.2 weeks 


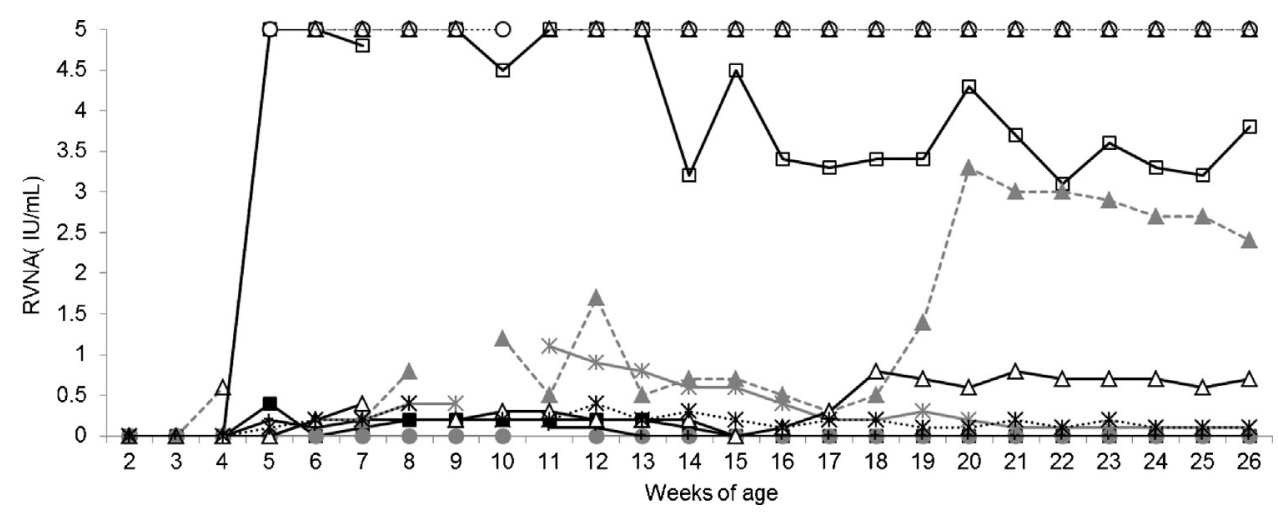

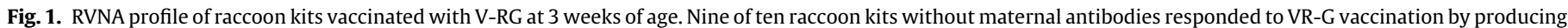
RVNA $\geq 0.1 \mathrm{IU} / \mathrm{mL}$ for at least five consecutive weeks. RVNA levels varied between individuals; seven kits still had detectable RVNA at 26 weeks post-vaccination.

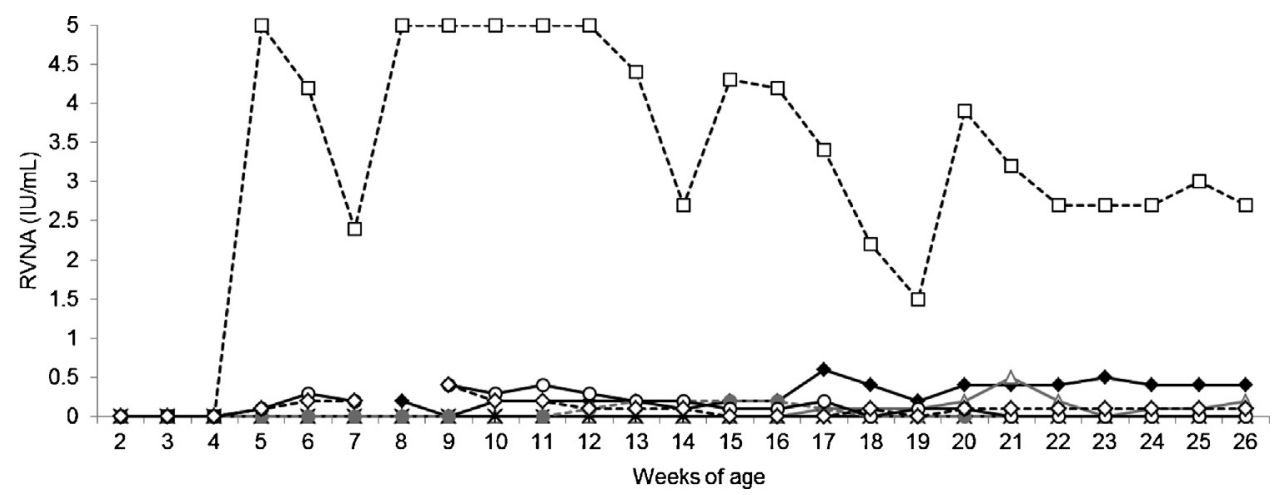

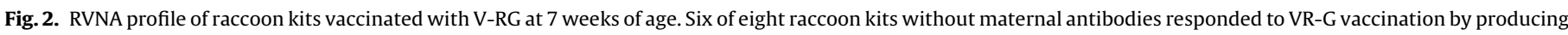
RVNA $\geq 0.1 \mathrm{IU} / \mathrm{mL}$ for at least five consecutive weeks. RVNA levels varied between individuals; four kits still had detectable RVNA at 26 weeks post-vaccination.

of age (range $=4-6$ weeks; Fig. 1 ). Eight raccoon kits were vaccinated at 7 weeks of age and 6 (75\%) developed RVNA at an average of 8.6 weeks of age (Range $=5-17$ weeks; Fig. 2). Eight raccoon kits were not orally vaccinated and served as contact controls; four of these kits (50\%) developed RVNA at an average of 6.25 weeks of age (Range $=5-9$ weeks; Fig. 3 ). All raccoon kits that seroconverted $(n=19)$ had detectable levels of RVNA for at least five consecutive weeks. Thirteen of these raccoon kits $(68 \%)$ still had detectable RVNA at 26 weeks of age (one RVNA positive kit was euthanized on week 10 due to a pelvic deformity).

One litter ( $n=4$ kits) was whelped by a mother with detectable RVNA one month before whelping $(14.4 \mathrm{IU} / \mathrm{mL})$ and at weaning $(4.3 \mathrm{IU} / \mathrm{mL})$. All four kits had high levels of RVNA $(\geq 8.0 \mathrm{IU} / \mathrm{mL})$ at the first blood sampling (12 days old; Fig. 4). After 3 weeks of age, RVNA levels of all four kits fluctuated between $8.0 \mathrm{IU} / \mathrm{mL}$ and $15 \mathrm{IU} / \mathrm{mL}$ for several weeks until levels steadily declined from 10 to 12 weeks through week 26. By 26 weeks (11 weeks after weaning), 3 of 4 kits with maternally acquired antibodies still had detectable RVNA values of $0.1 \mathrm{IU} / \mathrm{mL}$, while 1 kit had no detectable RVNA.

\subsection{Immune responses of raccoon kits after second exposure to rabies vaccine}

Overall, 19/26 kits (73\%) that were whelped by seronegative mothers and exposed to V-RG produced RVNA levels of $\geq 0.1 \mathrm{IU} / \mathrm{mL}$

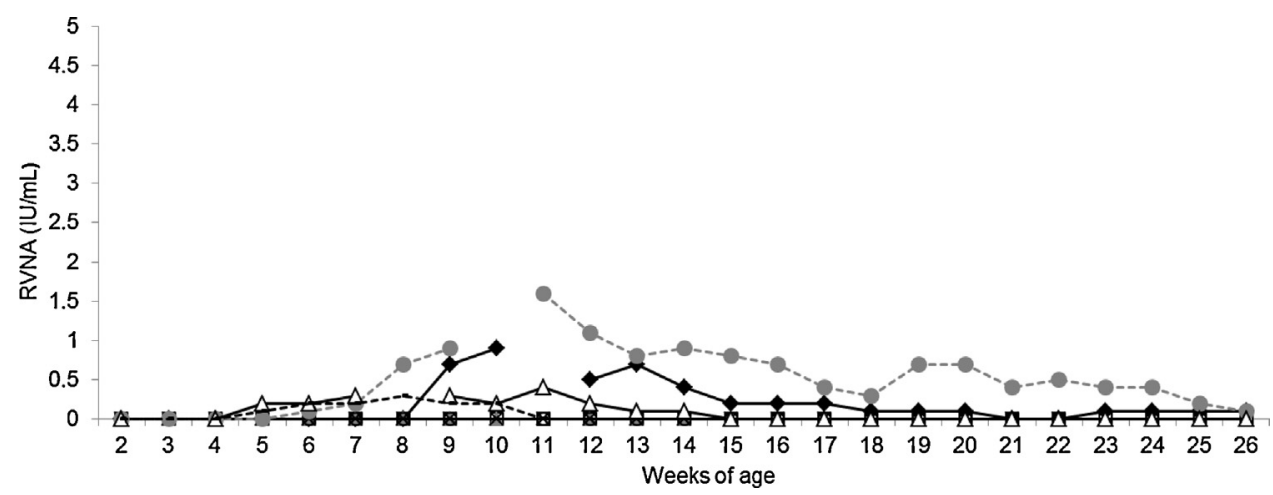

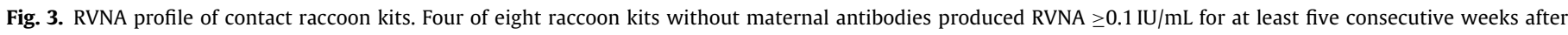
exposure to vaccinated littermates. RVNA levels varied between individuals; two kits still had detectable RVNA at 26 weeks post-vaccination. 


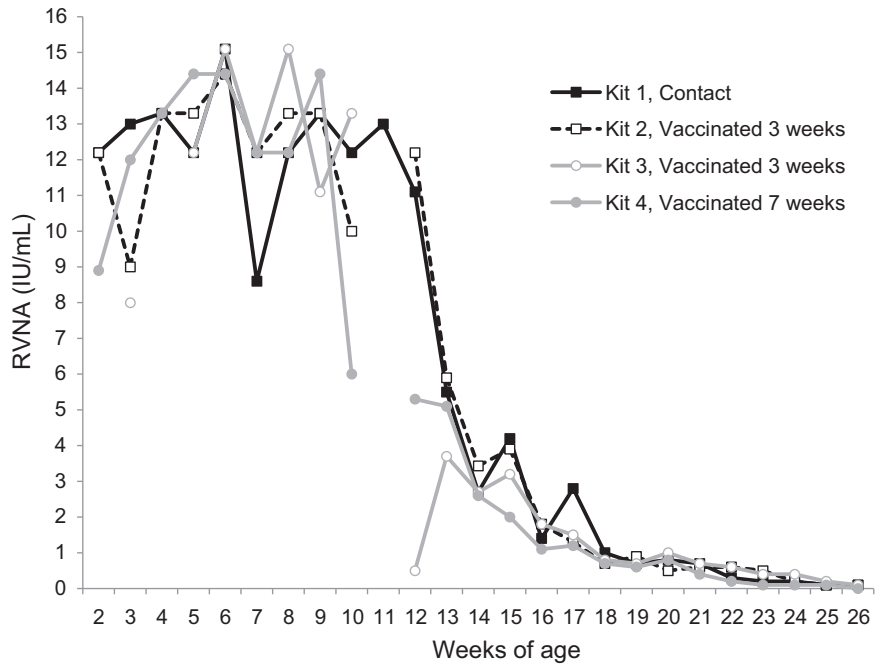

Fig. 4. RVNA profile of raccoon kits with maternally acquired antibodies. All four individuals exhibit a similar RVNA curve regardless of V-RG vaccination. At 26 weeks three raccoon kits still had detectable RVNA of $0.1 \mathrm{IU} / \mathrm{mL}$. The raccoon kit vaccinated at 7 weeks had undetectable RVNA at 26 weeks.

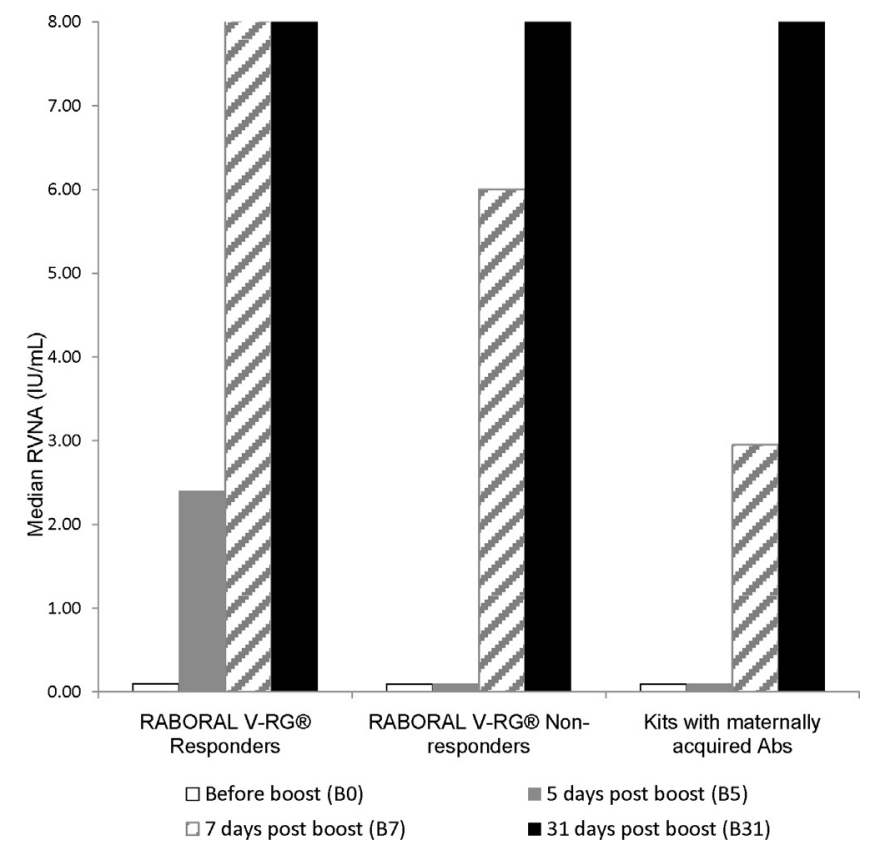

Fig. 5. RVNA profile of raccoon kits after a secondary rabies antigen exposure (IMRAB $3^{\circledR}$ ). All kits had previously been exposed to V-RG (orally or contact) and were designated as "Responders", "Non-responders", and "Kits with maternally acquired Abs" based on their primary response. Kits that responded initially to the V-RG exposure (RVNA $\geq 0.1 \mathrm{IU} / \mathrm{mL}$ ) appeared to have an anamnestic response to the IMRAB $3^{\circledR}$, while the other kits may have had a primary response.

for at least five consecutive weeks (designated as "responders"). Of the 19 responders, 15 were orally vaccinated and 4 were contact controls. Seven of 26 kits (30\%) failed to produce RVNA levels of $\geq 0.1 \mathrm{IU} / \mathrm{mL}$ (designated as "non-responders"). Following the subsequent vaccination with the killed rabies vaccine, IMRAB ${ }^{\circledR}$, we measured RVNA levels to assess any possible amnestic responses. "Responders" and "non-responders" differed significantly between day B0 and B5 and between day B0 and B7 $(P<0.05)$. No difference was observed between "responders" and "non-responders" by day B31. The 4 kits with maternally acquired antibodies had a similar RVNA profile as the "non-responders" (Fig. 5).

\section{Discussion}

Vaccination of young animals can be problematic. First, depending on species and age, their immune system may still be relatively immature and secondly, they may still have circulating antibodies acquired from their mothers that may interfere with vaccinations $[16,18-20]$. This is the first study to monitor the RVNA responses of very young raccoons (3-7 weeks of age) to V-RG and subsequent rabies vaccine exposure.

Twenty-six raccoon kits were whelped by mothers without detectable RVNA. While $90 \%$ of kits vaccinated at 3 weeks of age developed detectable RVNA $(\geq 0.1 \mathrm{IU} / \mathrm{mL})$ and $75 \%$ of kits vaccinated at 7 weeks of age developed detectable RVNA, the relatively low sample size does not have the statistical power to differentiate these two treatment groups. However, it appears that very young kits vaccinated at 3 weeks old responded as well as or better than kits vaccinated at 7 weeks old. In fact, of the 6 responders that were vaccinated at 7 weeks, three (50\%) developed RVNA at 5 weeks of age, suggesting that they were actually "vaccinated" by contact with 3 week vaccinates. Interestingly, $50 \%$ of our non-vaccinated contact kits also developed detectable levels of RVNA. These contact kits were most likely exposed to V-RG from suckling or playing with vaccinated kits. Limited horizontal transmission has previously been documented in other oral rabies vaccine experimental studies $[13,27,28]$. We did not observe any signs of disease or adverse effects associated with vaccination of these young animals and the overall seroconversion rate was similar to what we have observed in experimentally vaccinated adult raccoons [29]. Regardless of vaccination treatment, kits that developed RVNA also showed an anamnestic response after exposure to IMRAB $3^{\circledR}$ at $38-41$ weeks of age. Although we did not challenge the young raccoons with live rabies virus in this study, an anamnestic response to the rabies virus after oral vaccination has been previously shown to increase the likelihood of raccoon survival [23].

Because ORV baits are often dispersed in late summer/early autumn and because RVNA can still be detected in adult raccoons for many months after vaccination [30,31] it is possible that females would pass on maternal rabies antibodies to their young in the spring/summer. Three previous studies demonstrated that some fox cubs (Vulpes vulpes) born of rabies vaccinated mothers had detectable levels of RVNA in their serum for months [15-17], probably dependent on time of weaning. Two of our goals were to monitor the levels of maternally acquired antibodies in raccoon kits and investigate possible interference with oral rabies vaccination. Only a single mother had detectable RVNA one month prior to whelping so our ability to determine the importance of maternal antibody interference was limited to the analysis of four raccoon kits. We were unable to collect blood from the mother while she was nursing the kits. However, we were able to determine her RVNA levels one month prior to whelping $(14.4 \mathrm{IU} / \mathrm{mL})$ and when kits were weaned at 15 weeks ( $4.3 \mathrm{IU} / \mathrm{mL})$, levels adequate to allow antibody transfer during lactation. Regardless of vaccination treatment, the four kits whelped by this vaccinated mother had similar RVNA curves that fluctuated between $8.0 \mathrm{IU} / \mathrm{mL}$ and $15 \mathrm{IU} / \mathrm{mL}$ for several weeks until levels steadily declined through week 26 . Three out of four kits still had detectable RVNA at nine weeks post-weaning. If these RVNA were solely maternally derived (and not affected by active vaccination) then the half-life of maternal RVNA was approximately 10.5 days after weaning. This finding would be consistent with the duration of maternally acquired canine distemper virus (CDV) neutralizing antibodies, which had a half-life of 10.55 days after weaning [18].

Pare et al. [18] also showed that CDV neutralizing antibodies will nullify or interfere with subsequent CDV vaccination of raccoons at 8 weeks of age. Similarly, fox cubs with maternal RVNA $(\geq 0.5 \mathrm{IU} / \mathrm{mL})$ showed a significantly lower response to vaccination 
with an oral live attenuated vaccine SAD B19 (at 4-7 weeks) than fox cubs without maternal RVNA, suggesting that the maternal antibodies interfered with vaccination [16]. Another study demonstrated that fox cubs vaccinated with V-RG at 30 days or 90 days of age mounted similar immune responses regardless of the age at vaccination or immune status of the their mothers suggesting that no interference existed between passive immunity of maternal origin and active immunity conferred by V-RG oral vaccination [15]. However, in this study [15] all but one pup had maternally acquired RVNA values less than the threshold of the assay $(0.5 \mathrm{IU} / \mathrm{mL})$ at the time of vaccination.

To determine whether or not maternally acquired antibodies interfered with V-RG vaccination of raccoon kits, we looked for an anamnestic response to a second vaccination with IIMRAB3 ${ }^{\circledR}$. While kits that responded to the first vaccination (RVNA levels of $\geq 0.1 \mathrm{IU} / \mathrm{mL}$ ) showed a marked increase in median RVNA levels by 5 days post-IMRAB3 ${ }^{\circledR}$ exposure, kits that did not respond to the first vaccination (RVNA levels of $<0.1 \mathrm{IU} / \mathrm{mL}$ throughout sampling) and kits that had maternally acquired antibodies exhibited a slower increase in median RVNA levels. Although the data from this study are limited, the results indicate that maternally acquired antibodies may interfere with a kit's immune response to vaccination and that further investigation is warranted.

Overall, our data suggest that raccoon kits (3-7 weeks of age) are able to produce RVNA after oral vaccination with V-RG. These same kits are also able to mount an anamnestic response to a second rabies antigen exposure, which may be indicative of surviving rabies virus infection. However, it is possible that circulating maternally derived antibodies may interfere with active V-RG vaccination. If RVNA circulates in adult female raccoons through whelping and maternally acquired antibodies interfere with active immunizations then ORV programs must be cognizant of the timing ORV operations to account for this population segment of young raccoons unaffected by vaccination. The current timeline used by USDA APHIS Wildlife Services for ORV campaigns begins each year in early September when most young of the year are nearing 26 weeks old and no longer exhibiting maternally transferred antibodies, thus increasing the likelihood of success of the vaccine at the initial exposure to V-RG. There are of course exceptions, as it is possible that raccoon kits born later in the spring or early summer may experience interference between maternally acquired antibodies and vaccination, decreasing the success of ORV campaigns.

\section{Acknowledgements}

The authors would like to thank Dan Gossett and the animal care staff at NWRC for their assistance with the research. We would also like to thank Rebecca Riesen-Kruger for her guidance in blood collection from the neo-nates. Many NWRC technicians also assisted on the project including C. Ellis, J. Ellis, C. Minor, N. Mooers, R. Pleszewski, and T. Rigg.

\section{References}

[1] WHO. Rabies Factsheet. Available from: http://www.who.int/mediacentre/ factsheets/fs099/en/; 2012 [accessed 27.09.12].

[2] CDC. Rabies. Available from: http://www.cdc.gov/rabies/index.html; 2012 [cited September 2012]

[3] Smith JS, Orciari LA, Yager PA, Seidel HD, Warner CK. Epidemiologic and historical relationships among 87 rabies virus isolates as determined by limited sequence analysis. J Infect Dis 1992;166:296-307.
[4] Krebs JW, Rupprecht CE, Childs JE. Rabies surveillance in the United States during 1999. J Am Vet Med Assoc 2000;217:1799-811.

[5] Slate D, Chipmann RB, Rupprecht CE, DeLiberto T. Oral rabies vaccination: a national perspective on program development and implementation. In: Timm RM, Schmidt RH, editors. Proceedings 20th Vertebrate Pest Conference. 2002. p. 232-40.

[6] Vitasek J. A review of rabies elimination in Europe. Vet Med - Czech 2004;49:171-85.

[7] Slate D, Algeo TP, Nelson KM, Chipman RB, Donovan D, Blanton JD, et al. Oral rabies vaccination in North America: opportunities, complexities, and challenges. PLoS Negl Trop Dis 2009;3:e549.

[8] USDA/APHIS/WS National Rabies Management Program. Oral rabies vaccination. Available from: http://www.aphis.usda.gov/ws/rabies/vaccine.html; 2007 [cited September 2012].

[9] Guerra MA, Curns AT, Rupprecht CE, Hanlon CA, Krebs JW, Childs JE. Skunk and raccoon rabies in the eastern United States: temporal and spatial analysis. Emerg Infect Dis 2003;9:1143-50.

[10] Biek R, Henderson JC, Waller LA, Rupprecht CE, Real LA. A high-resolution genetic signature of demographic and spatial expansion in epizootic rabies virus. Proc Natl Acad Sci 2007;104:7993-8.

[11] Blanton JD, Palmer D, Dyer J, Rupprecht CE. Rabies surveillance in the United States during 2010. J Am Vet Med Assoc 2011;239:773-83.

[12] Whitaker JO, Hamilton W.J. Mammals of the Eastern United States. Ithaca: Cornell University Press; 1998.

[13] Rupprecht CE, Hamir AN, Johnston DH, Koprowski H. Efficacy of a vacciniarabies glycoprotein recombinant virus vaccine in raccoons (Procyon lotor). Rev Infect Dis 1988; 10. S803-S9.

[14] Langer P. Differences in the composition of colostrum and milk in eutherians reflect differences in immunoglobulin transfer. J Mammal 2009;90: 332-9.

[15] Blasco E, Lambot M, Barrat J, Cliquet F, Brochier B, Renders C, et al. Kinetics of humoral immune response after rabies VR-G oral vaccination of captive fox cubs (Vulpes vulpes) with or without maternally derived antibodies against the vaccine. Vaccine 2001;19:4805-15.

[16] Müller TF, Schuster P, Vos AC, Selhorst T, Wenzel UD, Neubert AM. Effect of maternal immunity on the immune response to oral vaccination against rabies in young foxes. Am J Vet Res 2001;62:1154-8.

[17] Hostnik P, Barlič-Maganja D, Toplak I, Grom J. The persistence of rabies virus antibodies in the sera of fox cubs. J Vet Med B 2003;50:204-6.

[18] Paré JA, Barker IK, Crawshaw GJ, McEwen SA, Carman PS, Johnson RP. Humoral response and protection from experimental challenge following vaccination of raccoon pups with a modified-live canine distemper virus vaccine. J Wildl Dis 1999;35:430-9.

[19] Cortese VS. Neonatal immunology. Vet Clin N Am-Food Anim Pract 2009;25:221-7.

[20] Welborn LV, DeVries JG, Ford R, Franklin RT, Hurley KF, McClure KD, et al. AAHA canine vaccination guidelines. J Am Anim Hosp Assoc 2011;47: $1-42$.

[21] Deresienski DT, Rupprecht CE. Yohimbine reversal of ketamine-xylazine immobilization of raccoons (Procyon lotor). J Wildl Dis 1989;25:169-74.

[22] Sikes RS, Gannon WL. Guidelines of the American Society of Mammalogists for the use of wild mammals in research. J Mammal 2011;92:235-53.

[23] Brown L, Rosatte R, Fehlner-Gardiner C, Taylor J, Davies J, Donovan D. Immune response and protection in raccoons (Procyon lotor) following consumption of baits containing Onrab ${ }^{\circledR}$, a human adenovirus rabies glycoprotein recombinant vaccine. J Wildl Dis 2012;48:1010.

[24] Smith JS, Yager PA, Baer GM. A rapid reproducible test for determining rabies neutralizing antibody. Bull World Health Organ 1973;48:535.

[25] Velleca WM, Forrester FT. Laboratory methods for detecting rabies: US Department of Health and Human Services, Public Health Service, Centers for Disease Control 1981.

[26] Moore SM, Hanlon CA. Rabies-specific antibodies measuring surrogates of protection against a fatal disease. PLoS Negl Trop Dis 2010;4:e595.

[27] Zhang S, Liu Y, Fooks AR, Zhang F, Hu R. Oral vaccination of dogs (Canis familiaris) with baits containing the recombinant rabies-canine adenovirus type-2 vaccine confers long-lasting immunity against rabies. Vaccine 2008;26: 345-50.

[28] Knowles MK, Nadin-Davis SA, Sheen M, Rosatte R, Mueller R, Beresford A. Safety studies on an adenovirus recombinant vaccine for rabies (AdRG1.3-ONRAB ${ }^{\circledR}$ ) in target and non-target species. Vaccine 2009;27:6619-26.

[29] Fry T, Van Dalen K, Hurley J, Nash P. Mucosal adjuvants to improve wildlife rabies vaccination. J Wildl Dis 2012;48:1042-6.

[30] Rupprecht CE, Wiktor TJ, Johnston DH, Hamir AN, Dietzschold B, Wunner WH, et al. Oral immunization and protection of raccoons (Procyon lotor) with a vaccinia-rabies glycoprotein recombinant virus vaccine. Proc Natl Acad of Sci 1986;83:7947-50.

[31] Rupprecht C, Hanlon C, Niezgoda M, Buchanan J, Diehl D, Koprowski H. Recombinant rabies vaccines: efficacy assessment in free-ranging animals. Onderstepoort J Vet Res 1993;60:463. 